\title{
MICROPALAEONTOLOGY NOTEBOOK \\ Freshwater Ostracoda from Tarawa, Kiribati: their implications for dispersal mechanisms
}

\author{
Stephen H. Eagar
}

Victoria University of Wellington, PO Box 600, Wellington, New Zealand

Tarawa Atoll, Gilbert Islands $\left(1^{\circ} 30^{\prime} \mathrm{N}, 173^{\circ} 00^{\prime} \mathrm{E}\right)$ is an isolated place, comparatively recently emergent -2500 years $\mathrm{BP}$ and $2-3 \mathrm{~m}$ above present sealevel (Marshall \& Jacobson, 1985). During the course of a study of the marine ostracods (Eagar, in press) it was noted that there are relatively few places where freshwater is visible on the surface of the atoll. This is not unusual, given the low precipitation $\left(154 \mathrm{~mm} \mathrm{a}^{-1}\right)$ and the daytime temperatures of Tarawa $\left(27-30^{\circ} \mathrm{C}\right)$. Five freshwater ponds on South Tarawa ( Fig. 1) were examined and two species of Ostracoda were found: Cyprinotus cingalensis Brady, 1886 and Limnocythere notodonta Vávra, 1906. At Bairiki (locality A), a pond adjacent to the causeway linking Bairiki with Betio was sampled and yielded abundant Cyprinotus cingalensis. Other ponds were found at Ambo (Locality B) and Temaiku Bight (Localities C and D with two ponds). Only the pond (Locality B), an established babai pit (taro; Cyrtosperma chamissonis), adjacent to the roadside at Ambo yielded further specimens of the ostracod Limnocythere notodonta, although in low numbers.

The question of how these species were introduced onto Tarawa Atoll is intriguing. C. cingalensis is known from Ceylon (Brady, 1886), Hawaii and the Sandwich Islands. The record by Vávra (1906) from Australia may be incorrect. Limnocythere notodonta was previously recorded only from Java (Vávra, 1906). Both species may have been distributed in the same way that Sars (e.g., Sars, 1896) transported species from different parts of the world to Norway to describe them. Dried mud was sent to him from desiccated ponds and then rehydrated to recover the faunas that survived the process. A discussion of dormancy in ostracods has been made by Horne \& Martens (1998). The present find endorses their view that limnocytherids have desiccation-resistant eggs. Of the dispersal methods described by McKenzie (1971), the eggs embedded in mud and stuck to birds' feathers or feet is the most feasible. However, on Tarawa, birds are mostly oceanic sea birds which are likely to land on the sea and wash off any mud. These migratory birds do not inhabit the ponds, but rather the reef flats. Since it is clear that ostracods can be transported in this manner, this is a possible mechanism for their introduction and

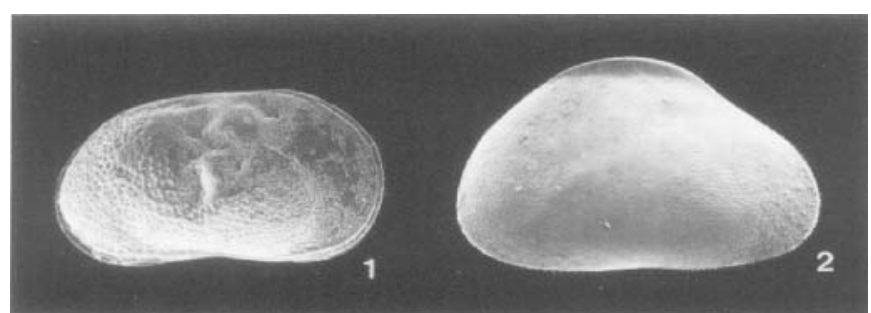

Explanation of Plate 1.

fig. 1. Limnocythere notodonta Vavra from Ambo: carapace from right side, length $0.45 \mathrm{~mm}$. OPI158 fig. 2. Cyprinotus cingalensis Brady from Bairiki: carapace from right side, length $1.20 \mathrm{~mm}$.OP1159. Specimens are held at the Institute of Geological and Nuclear Sciences, Lower Hutt, New Zealand. a more probable method is in mud dispersed passively by humans on machinery. Tarawa was part of the British Colony known as the Gilbert Islands from 1892 until independence in 1979. Governmental staff going there from the United Kingdom usually arrived via Australia and Banaba (Ocean Island). Opportunities to introduce ostracods to Tarawa on tools or machinery imported for construction purposes, either in the historic (gun emplacements, bunkers) or recent past (airport runway, foreign embassies) were many and varied. Large influxes of people occurred during World War II when Japanese occupied, the island together with some Korean workers. Subsequently, American forces landed at Betio during the Battle of Tarawa in 1943. Later, as part of an aid programme, the Japanese returned for the construction of the $3 \mathrm{~km}$ long Dai Nippon causeway linking Betio and Bairiki, and would have imported into Tarawa heavy machinery and other tools.

More recently there has been the importation of used cars and vans from Japan and ostracod eggs could have been imported on or in vehicle tyres and the pond adjacent to the causeway (Locality A) does have some old tyres in the water. This pond has only existed since the causeway was constructed in $1986-8$ and is in an area of active accretion that draws water from a nearby lens into the hollow in the coral sands. No explanation is offered for the introduction of species in the pond at Ambo but it was dug specifically for the cultivation of babai that grows in swampy conditions.

\section{Acknowledgements}

The author wishes to thank the New Zealand Ministry of Foreign Affairs and Trade and South Pacific Applied Geological Commission (SOPAC), Fiji for financial and logistical support; and Koen Martens, Koninklijk Belgisch Institut voor Natuurwetenschappen, Brussels for identification.

\section{Manuscript received 15 October 1999}

Manuscript accepted 3 March 2000

\section{REFERENCES}

Brady, G. S. 1886. Notes on Entomostraca collected by Mr A. Haly in Ceylon. Journal of the Linnean Society of Londan (Zoology), 19: 293-371.

Eagar, S. H. (in press) Use of Ostracoda in detection and recovery from sewage discharge into the marine environment in the tropical Pacific. In Martin, R. (Ed), Environmental Micropaleontology Plenum Press, New York:

Horne, D. J. \& Martens, K. 1998. An assessment of the importance of resting eggs for the evolutionary success of Mesozoic non-marine cypridoidean Ostracoda (Crustacea). Archiv fuerHydrobiologie, Special Issue Advances in Limnology 52:549-561.

Marshall, J. F. \& Jacobson, G. 1985. Holocene growth of a mid-Pacific atoll: Tarawa, Kiribati. Coral Reefs, 4: 11-17.

McKenzie, K. G. 1971. Paleozoogeography of freshwater Ostracoda. In Oertli, H. J. (Ed.) Pajéoécologie Ostracodes, Pau 1970. Bulletin Centre de Recherches Pau-SNPA, 5 (suppl): 207-237.

Vávra, V. 1906. Ostracoden von Summatra, Java, Siam, den Sandwich-Inselen und Japin. (Reise von Dr Walter Volz), Zoologische Jahrbuecher Abteilung fuer Systematik, Geographie und Biologie, 23: 413438

Sars, G. O. 1896. Contributions to the knowledge of the freshwater Entomostraca of New Zealand as shown by artificial hatching from dried mud. Videskabets-Selskabets Skrifier. I. Mathem-naturv. Klasse 5: 1-57,



Fig. 1. Map of south Tarawa showing localities examined for freshwater ostracods. 